\title{
Insect pollination and self-planting seed dispersal strategy in the true viviparous mangrove tree species Ceriops tagal (Perr.) C.B. Robinson (Rhizophoraceae)
}

\author{
K. Henry Jonathan ${ }^{1}$ \& A.J. Solomon Raju ${ }^{2}$ \\ 1,2 Department of Environmental Sciences, Andhra University, Visakhapatnam, Andhra Pradesh 530003, India \\ Email: ${ }^{2}$ ajsraju @yahoo.com (corresponding author)
}

\begin{abstract}
Ceriops tagal is a seaward and high salt-tolerant specialist mangrove species. It flowers during the winter season. The flowers have an explosive pollen release mechanism and are adapted for tripping by flies and honey bees. The tripped flowers achieve self or crosspollination. High winds can also trip flowers, but this only contributes to autogamy. The plant is viviparous; most propagules fall off and settle near the mother plant. We have observed that such propagules do not show healthy growth, hence the establishment of successive offspring in the same habitat is doubtful. These results suggest that $C$. tagal requires introduction of propagules from other mangrove forests to promote gene flow and maintain sufficient genetic diversity for the successful establishment and expansion of populations.
\end{abstract}

Keywords: Ceriops tagal, explosive pollination mechanism, insect pollination, vivipary, self-planting strategy

Date of publication 26 March 2009 ISSN $0974-7907$ (online) | 0974-7893 (print)

Editor: K.R. Sasidharan

\section{Manuscript details:}

Ms \# 01854

Received 05 September 2007

Final received 03 January 2008

Finally accepted 14 July 2008

Citation: Jonathan, K.H. \& A.J.S. Raju (2009). Insect pollination and self-planting seed dispersal strategy in the true viviparous mangrove tree species, Ceriops tagal (Perr.) C.B. Robinson (Rhizophoraceae). Journal of Threatened Taxa 1(3): 133-140.

Copyright: () K. Henry Jonathan \& A.J. Solomon Raju 2009. Creative Commons Attribution 3.0 Unported License. JoTT allows unrestricted use of this article in any medium for non-profit purposes, reproduction and distribution by providing adequate credit to the authors and the source of publication.

Author Details: See end of article.

Author contributions: K. HENRY JONATHAN has carried out field work, examined the material collected, and has tabulated and prepared the paper. DR. A.J. Solomon RaJu guided the field study, raise funds for the project, helped in preparation of the paper and is the corresponding author.

Acknowledgement: The financial support received through a Major Research Project [No.22/14/2004-CS (M)] from the Ministry of Environment and Forests, New Delhi is gratefully acknowledged. We thank Dr. S. Purnachandra Rao, SRA (CSIR) for his field assistance and photography.
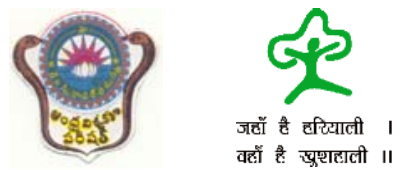

OPEN ACGESS | FREE DOWNLOAD

\section{INTRODUCTION}

The genus Ceriops is represented by two species, $C$. decandra and C. tagal, distributed from East Africa and Madagascar throughout tropical Asia and Queensland to Melanesia and through Micronesia north to Hong Kong (Tomlinson 1986). Both species have been reported to be useful in different ways, providing edible fruit, wood for boat making, house building and fuel, and bark for tannin extraction (used in treating fishing nets, as a binder for particle board and as an ingredient in alcoholic beverages, lotions for malignant ulcers and treatments for diabetes, malaria, leprosy; Burkill 1966; Perry 1980; Little 1983; Bechteler et al. 2006). The occurrence of the two species side by side is rare (Aksornkoae et al. 1992). Both are typical inner mangrove species, $C$. decandra often grows within the tidal zone mixed with other Rhizophoraceae (Tomlinson 1986) while C. tagal occurs in harder and higher muddy soil of polyhaline zone, forming pure stands on better-drained soils and showing stunted growth in exposed and highly saline sites (Tomlinson 1986; Aksornkoae et al. 1992; Selvam \& Karunagaran 2004).

In India, C. decandra is a common species in the interior tidal swamps and sporadic towards outer mangrove areas, while $C$. tagal is either rare or quite uncommon both on the east and west coasts. However, $C$. tagal has considerable population size in the mangrove forests of the Sundarbans, and on the Andaman and Nicobar Islands (Naskar \& Mandal 1999).

In Andhra Pradesh, mangrove forests occur in the Krishna and Godavari deltas, and C. decandra is a common constituent of these forests. There are conflicting reports regarding the occurrence of C. tagal in these forests. According to Untawale (1986), Banerjee et al. (1989), and Singh \& Odaki (2004), C. tagal occurs in the Krishna and Godavari deltas, but the Mangrove Status Report of the Ministry of Environment and Forests (1987) does not show its occurrence there. Naskar and Mandal (1999) also mentioned that it does not occur in Andhra Pradesh, citing the reports of different workers. Ramasubramanian et al. (2003) based on their field studies in the Krishna-Godavari mangrove forests and published a book which does not document the presence of C. tagal in these forests. However, our field studies showed the presence of C. tagal in Krishna mangrove forests. In this paper, we report on the pollination biology and seed dispersal ecology of C. tagal in Krishna mangrove forests, as existing information on these aspects is limited (Tomlinson 1986), especially under Indian conditions.

\section{Materials And Methods}

Krishna Mangrove Forests occur between $15^{\circ} 42^{\prime}-15^{\circ} 55^{\prime} \mathrm{N} \& 80^{\circ} 42^{\prime}-81^{\circ} \mathrm{O} 1^{\prime} \mathrm{E}$ spread across Krishna and Guntur districts in Andhra Pradesh. Around 60 trees of C. tagal occur seaward on a well-drained muddy soil in Nachugunta reserve forest in Krishna district (Fig. 1). The area is well-drained during low tide periods and flooded with seawater during high tide periods. Ten accessible trees of C. tagal were used for the present work. Fortnightly field trips were conducted to visit these trees until the onset of flowering, 


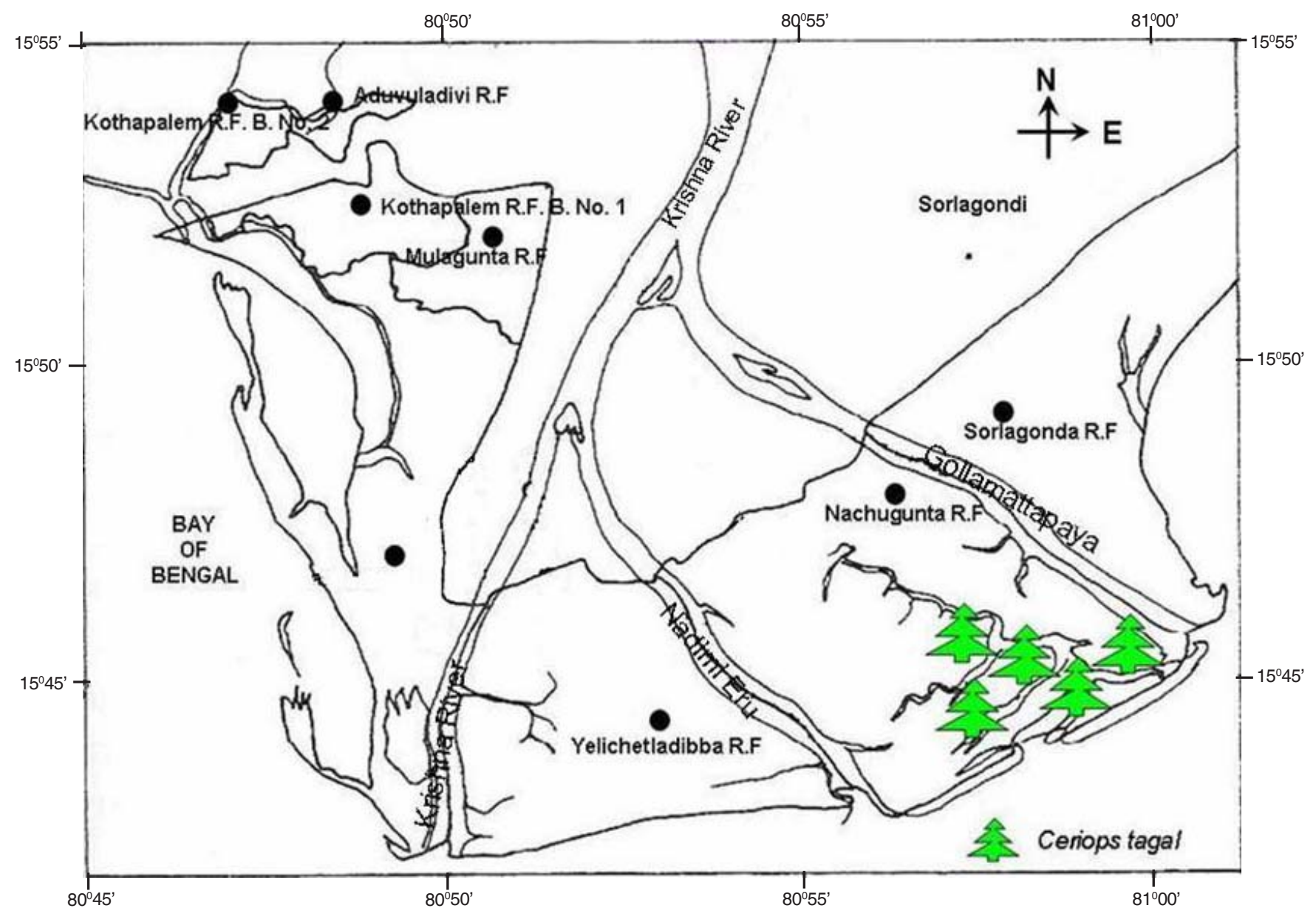

Figure 1. Location of Ceriops tagal in Krishna Mangrove Forest

and regular field studies were conducted during the entire period of flowering and until seedlings fell down during 2005-2006. Floral, structural and functional details were examined according to the protocols given by Dafni et al. (2005). Nectar characteristics including volume, sugar concentration, sugar types and amino acids were examined according to the methodologies provided by Roubik (1995) and Baker \& Baker (1973). Flower visitors were observed for their role in effecting pollination. Five individuals each of bees and ten individuals of a fly species were captured, washed in aniline blue on a glass slide and the number of pollen grains counted under a microscope to determine their role in pollen transfer. As the flowers have an explosive pollen release mechanism, the role of wind in petal explosion and subsequent pollination was also observed during day time. For this, five easily-accessible inflorescences with newly open flowers exposed to direct sunlight towards creek side in the windward direction were tagged and bagged carefully in the evening of the previous day; bags were removed carefully in the morning of the next day and the tagged inflorescences observed at close quarters until late evening to note whether petal explosion occurred. Care was taken to prevent foragers from visiting these inflorescences throughout the observation period. Twenty inflorescence with 262 mature buds from ten trees were bagged and followed for fruit/seedling production to judge whether breeding system is vector dependent. One inflorescence each from 10 trees with a total of 123 flowers were tagged and followed to note flower abortion rate. In these inflorescence, flowers fell off two days after anthesis against the actual flower life, and this early flower drop was recorded as flower abortion. Sixty-four open inflorescence with 704 flowers from the same set of trees were tagged and followed for natural fruit set at the site. Fruit and seedling development and characteristics were also investigated in detail by following fruited flowers until propagules fell down. Visual observations on the dispersal and establishment of propagules at the study site were made to understand the planting strategy.

\section{Results}

C. tagal is an evergreen shrub/tree (Image 1a) and flowers during November-February. Its associate plant species, Aegiceras corniculatum (December-March), Bruguiera gymnorrhiza, Rhizophora apiculata and Ceriops decandra (year-long) also show flowering simultaneously. In C. tagal, the flowers are born in condensed short-stalked cymes formed from dichotomizing panicles, which arise from the axils of leaves on the terminal nodes of new shoots (Image $1 \mathrm{~b}, \mathrm{c}$ ). A cyme produces $11 \pm 2.5$ flowers which anthese over a period of 6-8 days (Image $1 \mathrm{~d}, \mathrm{e}$ ). Flowers are short-stalked, small, white, cup-shaped, strongly fragrant, bisexual and zygomorphic. Sepals are five, small, yellowish-green, valvate enclosing the inner parts until anthesis and not reflexed after anthesis. Petals are five, free, white, pubescent, two lobed, and alternating with the sepals. The lower 

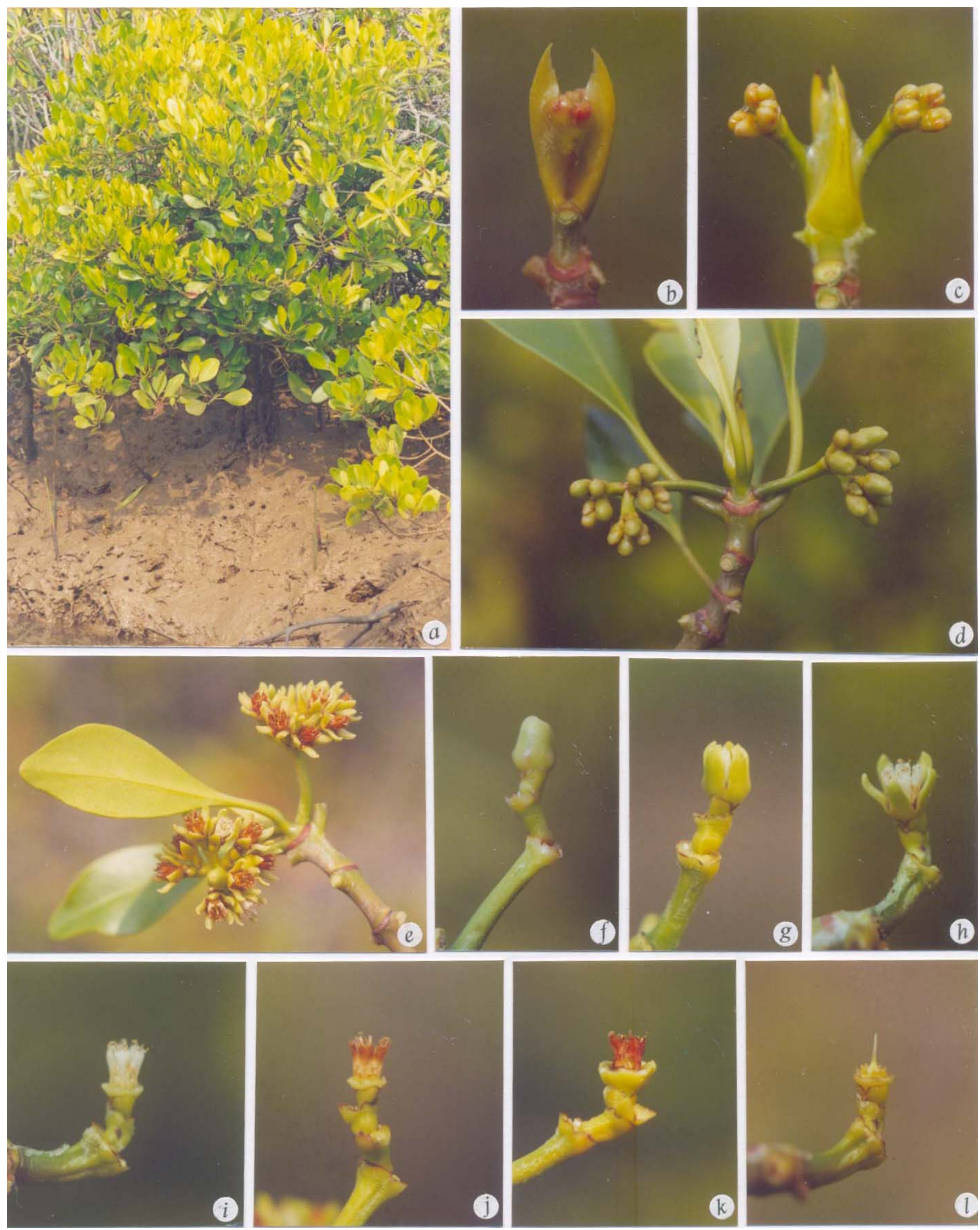

k

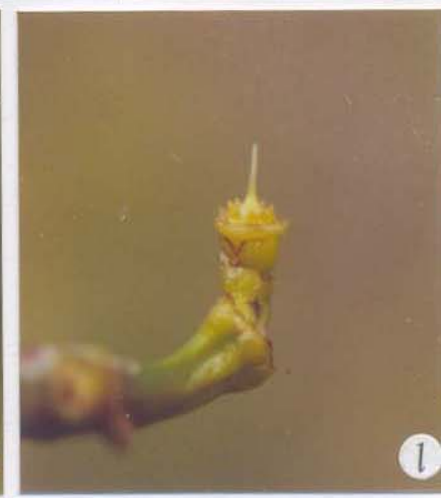

Image 1. Ceriops tagal. a - Habit; b \& c - Short-stalked cymes emerging from the axils of leaves; $d$ - Fully developed cymes; e - Flowering cymes; f - Mature bud; g - Partly open mature bud; h - Fully open flower; i - Petals with stamens inside and overtopped by filamentous appendages; j \& k Gradual petal colour change from the top to base; I - Flower showing style and stigma 

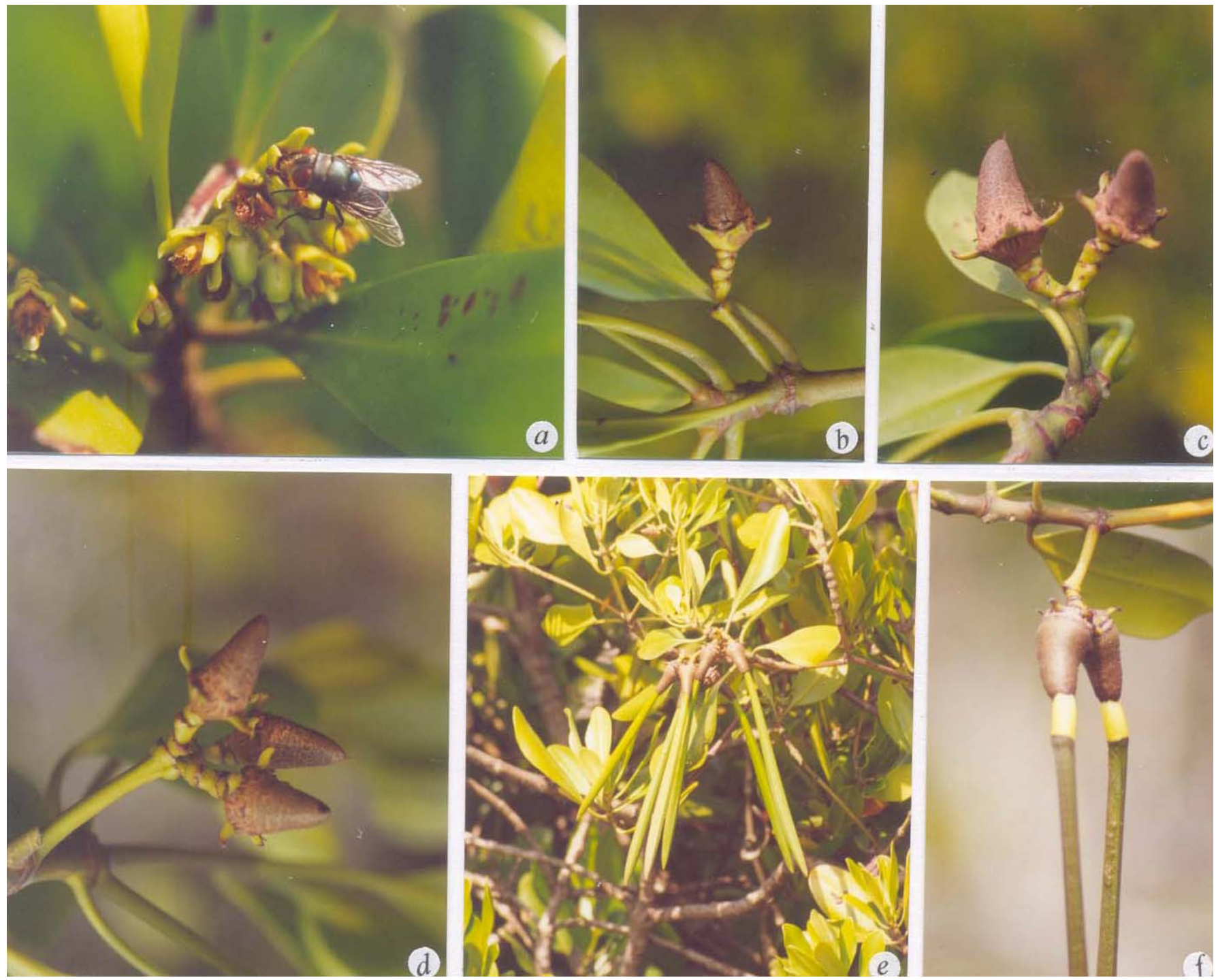

Image 2. Ceriops tagal. a - Chrysomya megacephala feeding on nectar; b-d - Fruited cycmes (b - one-fruited; c - two-fruited; $d$ - threefruited); e - Growing propagules; $f$ - Cotyledonary yellow collar distinguishing the fruit from the hypocotyl.

margins of adjacent petals are held together by patches of tightly intertwining, helically coiled hairs. Each petal has three distinct clavate appendages on its distal margins. Stamens are 10 , five of them antisepalous, five others antipetalous and all 10 inserted on the rim of the calyx cup. Each petal encloses the antipetalous stamen and an adjacent antisepalous stamen; the two stamens remain in the petal under tension enclosed above by the clavate appendages even after anthesis. The style is slender and terminated into minute separate stigmatic lobes. The stigma stands at the height of the stamens (Image 11). Disc within the stamen ring is well developed and anther lobes enclose the base of the thick filaments. Ovary is semi-inferior, 3-carpelled and 3-locular with a total of six ovules.

The mature buds open during 1630-1800hr. The calyx lobes separate at anthesis and diverge to expose the petals (Image 1f-h). The petals with the stamens inside, two per petal do not unfold naturally throughout the flower life but remain in a state of tension with the spring-loaded stamens hooded above by clavate appendages (Image 1i). Anther dehiscence occurs in bud. Pollen grains are triangular, light yellow, exine smooth and $15 \mu$ in diameter. A flower produces $14,681 \pm 25.62$ pollen grains. The pollen-ovule ratio is 2,446:1. The stigma attains receptivity on the second day and remains receptive up to six days. But, peak receptivity occurs from third to fifth day. During this period, the white petals turn red gradually from the top to the base (Image $1 \mathrm{j}, \mathrm{k}$ ). A flower produces $5.65 \pm 1.0$ $\mu \mathrm{l}$ of nectar. The nectar sugar concentration is $35-50 \%$ and the common sugars include fructose, sucrose and dextrose with the first relatively more dominant. The nectar contains 12 amino acids which include tyrosine, glycine, methionine, proline, lysine, aspartic acid, glutamic acid, serine, cysteine, alanine, threonine and arginine. Of these, glycine, serine, cysteine, alanine and threonine are relatively dominant. The amino acids such as phenylalanine, valine, leucine, iso-leucine, tryptophan and histidine were not found in the nectar. The unpollinated flowers fall off on seventh day. In pollinated flowers, the petals, stamens, the style and stigma drop off in this order in 3-4 weeks while the fruit is in growing stage. The sepals are persistent, become warty and spiny gradually and remain on the plant even after the shedding of propagules.

The buds produced proceed to open without abortion. In open flowers, flower abortion rate is $42 \%$. Of the 20 


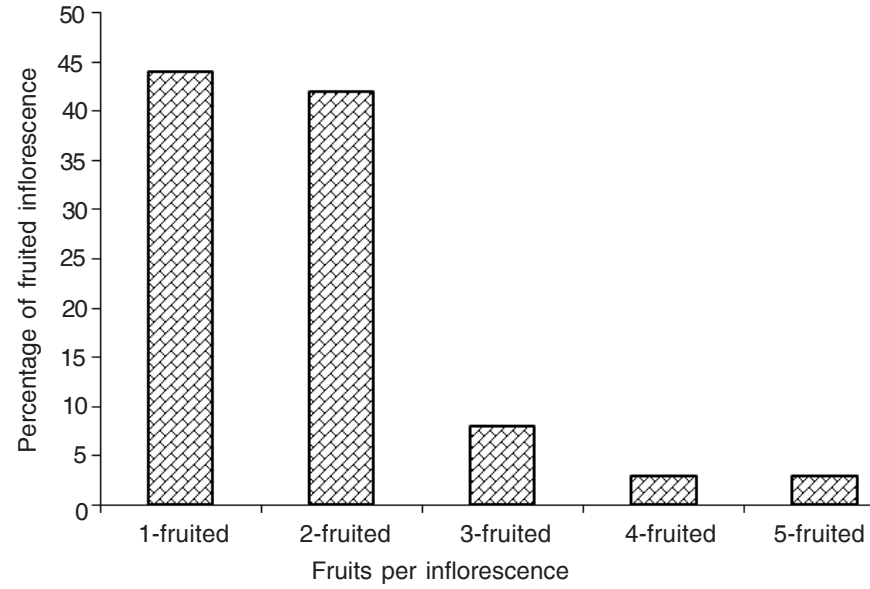

Figure 2. Fruit set rate at inflorescence level in $C$. tagal

inflorescence bagged, only eight flowers set fruits and thus the fruit set in bagged flowers is $3 \%$. Of the 64 open inflorescence tagged, only 115 flowers set fruit, constituting 16.3\% natural fruit set. Fruit set per inflorescence varied from 1 to 5 but 1and 2 -fruited inflorescence were more common (Image $2 \mathrm{~b}-\mathrm{d}$ Fig. 2). The pollinated flowers take four weeks to produce mature fruits, which are single seeded. Fruits are conical by the extrusion of the upper part of the ovary, surface brown and roughened. The seed has no dormancy and produces hypocotyls while on the mother tree in a span of about two months. The cotyledonary yellow cylindrical collar ( $1 \mathrm{~cm}$ long; Image $2 \mathrm{f}$ ) appears from the fruit about 10 days prior to detachment of the hypocotyls. The hypocotyl is $26 \mathrm{~cm}$ long, distinctly ridged and hangs downwards. It is initially green (Image 2e), after the development of collar it shows a gradual colour change to brownish-purple from hypocotyls end to plumule. The mature hypocotyls separate from fruit, leaving the latter attached to the mother plant. The detached hypocotyls were found to settle in the vicinity of the mother plant.

The flowers do not expose stamens naturally, but the latter attain a tensed condition in the delicate petals for release by a delicate external touch. The foragers included honeybees, Apis cerana indica, A. florea and a fly species, Chrysomya megacephala (Image 3a). Of these, honeybees foraged for pollen and nectar occasionally while the fly foraged for the nectar consistently until the floral source exhausted. All three species approached the flower from above and probed for nectar, causing sudden release of stamens from the petals. In effect, the pollen from the already dehiscent anthers was ejected forcibly and deposited on the underside of the foraging bee or fly. Body washings for pollen revealed the presence of pollen grains which varied from 231 to 413 per bee and from 79 to 147 per fly suggesting that both bees and the fly have an important role in petal explosion and pollination. In case of bees, they also carried pollen loads in pollen baskets present on their legs. As each petal independently encloses two stamens, a single foraging visit of the bee or fly did not result in the explosion of all five petals. Both the bees and the fly tended to visit more than one flower on the same inflorescence or different inflorescences on the same plant before flying away to visit the neighboring trees, and may return back again to visit the same flowers later. As they tended to move back and forth between trees, their foraging activity may result in substantial self- and cross- pollination. The honey bees were found to concentrate principally on B. gymnorrhiza and $A$. corniculatum while the fly species was exclusively observed on $C$. tagal.

We observed that the explosion of petals in open flowers was also triggered by the action of wind. The plant grows in the seaward zone and high winds are characteristic of the site. Of the 24 flowers observed, four had shown petal explosion triggered by wind action, indicating that $16.6 \%$ of flowers may achieve pollination by wind action. In such flowers also, the explosion of all five petals did not take place at one time. It had not been possible to study whether wind could trigger petal explosion in the flowers located on the branches facing the landward direction and mixed with the canopy where wind action becomes relatively ineffective. Wind-triggered petal explosion may result in autogamy.

\section{Discussion}

C. tagal is strictly a winter bloomer, whereas its closely related species $C$. decandra is a year-long bloomer with alternate flowering and fruiting phases (Raju et al. 2006). Aksornkoae et al. (1992) reported that the occurrence of the two species at the same site is rare; we also found a similar situation at the Krishna mangrove forests. The distribution of C. tagal in this forest indicates that it has a distinct seaward zonation and prefers welldrained high saline soils, suggesting that the species is a salttolerant mangrove with the competitive ability to grow in highly saline and partly inundated locations (Aziz \& Khan 2001). The site is flooded with water only during high tides and is well drained during low tides indicating that C. tagal is a higher intertidal mangrove specialist; the plants occurring in such sites are inundated about 20 times a month (Duke et al. 1998). Further, in such sites rains make no difference, and hence the salt content of the soil remains high and approximately uniform throughout the year(Joshi 1933). Duke et al. (1998) reported that Excoecaria agallocha becomes more common in the absence of C. tagal in such sites. At the study site, a few trees of C. tagal occur with some naked habitat and E. agallocha grows here and there in its association. On the contrary, C. decandra is not a strict seaward mangrove plant and it occurs commonly even in areas of tidal zone far away from sea shore(Tomlinson 1986). Our field studies in mangrove forests in Andhra Pradesh showed that C. tagal is absent in the Godavari mangrove forest, while a few trees still survive in Krishna mangrove forests. Therefore, C. tagal being a seaward mangrove has not been successful in establishing a good population size, while its sister species, C. decandra with flexibility to survive in tidal zones even far away from the seashore, has built up its populations to the extent of becoming a common constituent of mangrove forests.

In C. tagal, the floral characteristics such as white flowers, strong fragrance, complex petal-stamen configuration and production of moderate amount of nectar suggest an elaborate and specialized floral mechanism. The petals require an external delicate touch for the explosive release of stamens. The helically-coiled hairs at the lower margins of the petals help to propagate explosive pollen release effectively (Juncosa \& Tomlinson 1987). The petal clavate appendages of petals in C. tagal lack hydathodes and abundant xylem which are characteristically present and have a role in flower function under extreme water pressure deficits during the day in $C$. decandra (Juncosa \& Tomlinson 1987). Such a state may make 
appendages light and provide necessary trigger for petal explosion by the delicate touch of the forager in C. tagal. An explosive pollination mechanism has also been reported in Bruguiera species for which the flower-tripping agents are birds and butterflies (Tomlinson et al. 1979; Ge et al. 2003).

Tomlinson (1986) reported night-flying insects, especially moths as probable pollinators. Meeuse \& Morris (1984) described the characteristics of moth flowers, which include: flower opening in the evening, display of overwhelming fragrance at that time, light flower colour, absence of a landing platform, fringed petals for guidance, visual and olfactory nectar-guides, long and narrow corolla tube, abundance of nectar and short-tongued visitors. Baker \& Baker (1983) reported that hawk moth flowers produce sucrose-rich or dominant nectar with low sugar concentration. Cruden et al. (1983) reported that small moth flowers produce relatively small volumes of nectar with small amount of sugar. They also stated that moth flowers initiate nectar secretion 1-3 hours or even 10 or more hours prior to the activity period of moths. In C. tagal, nectar guides and tubular corolla are lacking, the nectar secretion begins an hour after anthesis; it is in moderate volume, hexoserich with high sugar concentration. These characters together with the shallow nature of flowers are suitable for foraging by short-tongued bees and flies (Baker \& Baker 1983; Cruden et al. 1983). In our study we have not found the foraging activity of hawk moths or settling moths at the flowers after anthesis until late evening (up to $2200 \mathrm{hr}$ ), and the absence of moths could be due to non-availability of nectar at anthesis and reduced opportunities for food and breeding opportunities in harsh mangrove habitats. C. tagal with a few trees and a few numbers of flowers per unit of time per tree does not constitute a potential nectar station for moths. Further, adult moths do not survive for longer period and in particular, hawk moths may survive for a period exceeding a month (Opler 1983). Within that life span, the availability of nectar in the habitat is crucial and since C. tagal is unable to attract and supply its nectar requirement, the moths might have disappeared or migrated to other reliable food-rich habitats. Apis bees and Chrysomya flies make up day-time foragers for C. tagal. With a small number of trees and again each tree with a small number of flowers per day, C. tagal is not a potential pollen and nectar source for honey bees. Yao et al. (2006) also reported that this plant species is a minor pollen and nectar source for honey bees. In the study site, Aegiceras and Bruguiera flowers attract honey bees and the latter were found concentrating on these species. Chrysomya flies frequent the flowers of C. tagal daily effecting pollination but they have limited pollen transport capacity; this however, is compensated by their numbers and could bring about substantial geitonogamy and xenogamy (Faegri \& van der Pijl 1979). The petal colour change may act as a nectar guide for the flies to visit the flowers for several days. The close proximity between trees of C. tagal at the study site also facilitates xenogamy. The fly is present throughout the year unlike periodic bees and moths; but its presence depends on local opportunities for breeding sites (Faegri \& van der Pijl 1979). Our observations suggest that Chrysomya is the primary and consistent pollinator while honey bees are secondary and occasional pollinators. Petal explosion also occurs sporadically in nature due to wind action and this is evident in bagging experiment in which there is a negligible fruit set and also in natural conditions to some extent. The role of wind in tripping explosive pollination has also been reported in Hyptis suaveolens (Lamiaceae) (Raju 1990) and Shorea robusta (Dipterocarpaceae)(Atluri et al. 2004). Therefore, petal explosion and subsequent pollination events are primarily vectordependent and inadequate numbers or non-availability of pollinators are bound to result in reduced or no fruit set in $C$. tagal.

Honey bees respond to differences in amino acid concentration and detect amino acids. They prefer certain amino acids and their presence make nectar more attractive (Dress et al. 1997). Tyrosine is not an essential amino acid but may be important in the formation of sclerotin (Gardener \& Gillman 2002). Phenylalanine is a precursor of specific honey aroma component, phenyl-ethanol (Thawley 1969), iso-leucine is required for rapid breeding (Slansky \& Feeny 1977). Flies also prefer amino acids in nectar. In the flies, Boettcherisca peregrine and Phormia regina, proline stimulates salt receptor cells, methionine and valine stimulate sugar receptors, methionine also elicits a feeding response from flies and glycine and serine invoke an extension of the proboscis (Shiraishi \& Kuwabara 1970; Goldrich 1973). C. tagal flowers with a mix of floral characteristics of moth, bee and fly flowers contain conventional protein building amino acids such as tyrosine, glycine, methionine, proline, lysine, aspartic acid, glutamic acid, serine, cysteine, alanine, threonine and arginine but are devoid of other protein-building amino acids such as phenylalanine, valine, leucine, iso-leucine, tryptophan and histidine. The nectar provides an instant supply of methionine, lysine and arginine for honey bees and flies; moths if occur in the habitat also make use of this nectar for protein building. The presence of several amino acids in this nectar source stimulates feeding and may also be an important source for flower foragers.

In viviparous mangrove plants, mixed mating system has been reported in Bruguiera gymnorrhiza, Kandelia candel, Rhizophora mucronata and R. mangle; the first three species are mainly out-crossing while the last is predominantly selfpollinating (Ge et al. 2003; Sun et al. 1998; Chen et al. 1996; Kondo et al. 1987). In such species, out-crossing rates vary between populations and affected by plant density, population structure, pollinators, adaptability and self-incompatibility. Environmental factors may disrupt and bring about distinct out-crossing rates (Ge et al. 2003). C. decandra as a common species in most of the regions in its distribution range may have achieved distinct out-crossing rates and accordingly, it has been reported to be an out-crosser (Raju et al. 2006). On the contrary, C. tagal with a small number of individuals at the study site can produce offspring with mixed mating system only if it fails to attract potential and adequate pollinators. In line with this, we found that it possesses such a system to produce fruit set even through autogamy. But, autogamy is negligible as realized in our bagging experiment. In K. candel and also in a crypto-viviparous species, Avicennia marina, negligible selfpollination has been reported in bagging experiments (Sun et al. 1998; Clarke \& Myerscough 1991). The fruit set in C. tagal is through geitonogamy and xenogamy. The long flower life and stigma receptivity and high pollen-ovule ratio (Cruden 1977 ) indicate that the plant is primarily out-crossing. However, the close proximity of the existing trees at the study site in course of time could bring about genetic uniformity and if this happens, the survival of this species becomes doubtful. 
Ceriops decandra displays a high per cent of bud and flower abortion. In C. tagal, there is no bud abortion but it shows a high per cent of flower abortion. This abortion could be due to defective nature of the flowers and adjustments of the available resources to growing healthy fruits and seedlings in order to prevent premature fruit abortion. The number of fruits per inflorescence varies from 1 to 5 but 1 - and 2 -fruited inflorescences are most common. The fruited flowers produce only one seed against the actual number of six ovules as in $C$. decandra and all other viviparous species of Rhizophoraceae. This characteristic may permit these plants to save resources and use them to produce one-seeded viable fruits. Despite this effort by C. tagal, a few propagules lack green pigment and becoming entirely yellowish or yellowish on one side and purplish on another side. Such hypocotyls have been referred to as "albino" forms which also occur in C. decandra and Bruguiera gymnorrhiza (Raju et al. 2006; Allen \& Duke 2006). These propagules are non-viable, cannot photosynthesize and die after depleting reserves if settled in the habitat. The propagules that are green first and brownish-purple later are healthy and grow to their actual size. The length of hypocotyls in C. tagal is almost double the length of hypocotyls in $C$. decandra. Both the species of Ceriops show a short period of attachment to the maternal plant (Raju et al. 2006) and this characteristic is not in agreement with the report of Bhosale \& Mulik (1991) that the hypocotyls of true viviparous mangrove species remain attached to the mother plant for a full year. The hypocotyl grows upward in $C$. decandra in which flowers are sessile (Raju et al. 2006) while in C. tagal, it grows downward which seems to be because of stalked flowers and more weight of the hypocotyls. This is an important field characteristic feature to distinguish C. tagal from C. decandra. The downwardly hanging hypocotyl is also a characteristic of Bruguiera, Rhizophora and Kandelia species. In C. tagal, the cotyledonary yellow cylindrical collar emerges from the fruit about 10 days prior to the detachment of the hypocotyl while this structure is entirely absent in C. decandra (Raju et al. 2006). The cotyledonary collar is a characteristic also in Rhizophora in which it is reddish brown and Kandelia in which it is yellow and the hypocotyl is about double the length of C. tagal (Aksornkoae et al. 1992).

Fruit in C. tagal grows continuously and the seed also has no dormancy like in other mangrove species of Rhizophoraceae (Farnsworth \& Farrant 1998). This form of fruit growth and seed germination leading to the formation of hypocotyl while still attached to the mother plant represents "vivipary", the opposite of "ovipary" in which seed dormancy is the rule. The viviparous condition has been considered as an evolutionary loss of seed dormancy (Farnsworth \& Farrant 1998), however, it is an adaptive feature for the plant to overcome the harsh tidal environment for seedling establishment in the parental sites but it is not considered adaptive for dispersal either in time or space (Sun et al. 1998). The other adaptive values of vivipary include facilitation of early rooting (MacNae 1968), buoyancy during sea dispersal (Rabinowitz 1978), transfer of maternal nutrients to the hypocotyls (Pannier \& Pannier 1975), maintenance of embryonic osmotic equilibrium, establishment in coarse grained environments. On the other hand, vivipary incurs maternal costs to supply water and necessary nutrients. Numerous attached seedlings may constitute a substantial carbon sink to the maternal plant, a concentrated apparent resource for herbivores (Farnsworth \& Farrant 1998). C. tagal at the study site was found to produce 20 to 60 hypocotyls per tree and it is not known whether this small number could attract herbivores.

Kairo et al. (2001) reported that viviparous mangrove species use self-planting or stranding strategy for establishment depending on forest conditions tide and stability of the soils. The self-planting strategy dominates in undisturbed mangrove forests but stranding strategy is dominant in exploited and open or naked forests (Dahdouh-Guebas et al. 1998). C tagal with epigeal seed germination, elongated and pointed hypocotyls with straight curvature (Clarke et al. 2001) fall freely from the mother plant and plant themselves into the mud at the same site during low tide period. The hypocotyls if fallen during high tides float to another site for settlement. But, our field studies do not show settlement of hypocotyls away from the mother plants suggesting that $C$. tagal uses self-planting strategy only. This is further substantiated by McGuinness (1997) who also reported that hypocotyls of C. tagal in northern Australia dispersed very short distances; only $9 \%$ moved more than $3 \mathrm{~m}$ from the parent tree. He also mentioned that within that short distances, a high percentage of them were either damaged or eaten by animals. C. tagal at the study site may also be experiencing the damage or consumption by animals, especially crabs as the latter have been reported to show high predation on hypocotyls in high inter-tidal areas (Duke et al. 1998). Some of the fallen hypocotyls settled at the mother plants showed signs of withering. Therefore, the study suggests that $C$. tagal though occurring in undisturbed and human-free site is almost unable to add new plants and the presence of only a few individuals at the site attests this contention. The work reported in this paper is important for initiating studies on the genetic structure of $C$. tagal population. The genetic marker analysis may help to understand the variability within and between different populations. Introduction of C. tagal from the mangrove forests of the Sundarbans and Andaman and Nicobar Islands to this site would help to enhance gene flow in order to maintain the gene diversity and expansion of population size of C. tagal in Krishna Mangrove Forests.

\section{References}

Aksornkoae, S., G.S., Maxwell, S. Havanond \& S. Panichsuko (1992). Plants in Mangroves. Chalongrat Co., Ltd., Thailand, 120pp.

Allen, J.A. \& N.C. Duke (2006). Bruguiera gymnorrhiza (large-leafed mangrove): Species Profiles for Pacific Island Agroforestry. www.traditionaltree.org

Atluri, J.B., S.P.V. Ramana \& C.S. Reddi (2004). Explosive pollen release, wind-pollination and mixed mating in the tropical tree Shorea robusta Gaertn. F. (Dipterocarpaceae). Current Science 86:1416-1419.

Aziz, I. \& M.A. Khan (2001). Experimental assessment of salinity tolerance of Ceriops tagal seedlings and saplings from the Indus delta, Pakistan. Aquatic Botany 70: 259-268.

Baker, H.G. \& I. Baker (1983). A brief historical review of the chemistry of floral nectar, pp. 126-152. In: Bentley, B. \& T. Elias (eds.), The Biology of Nectaries. Columbia University Press, New York.

Baker, H.G. \& I. Baker (1973). Some anthecological aspects of the evolution of nectar producing flowers particularly amino acid production in nectar; pp.243-264. In: Heywood, V.H. (ed.). Taxonomy and Ecology. Academic Press, New York

Banerjee, L.K., A.R.K. Sastry \& M.P. Nayar (1989). Mangroves of India. Botanical Survey of India, Govt. of India, 113pp.

Bechteler, A., A. Pilkama, E. Permana, J. Poellath, K. Prasanai, S. Rahaju, S. Pessala \& S.A. Alam (2006). Coastal zone management in Southeast Asia. Case: Mangroves and tsunami effects in Thailand. Report for ME 451: 
Tropical forest landscape restoration in Southeast Asia (Fifth International Course on Tropical Forest Ecology and Silviculture).

Bhosale, L.J. \& N.G. Mulik (1991). Strategies of seed germination in mangroves. pp. 201-205. In: David, N.S. and Mohammed, S. (editors), Proc. International Seed Symposium, Jodhpur, India.

Burkill, J.H. (1966). A Dictionary of Economic Products of the Malay Peninsula. Art Printing Works, Kuala Lumpur, 2 Vols, 1904pp.

Chen, X-Y., P. Lin \& Y.M. Lin (1996). Mating system and spontaneous mutation rates for chlorophyll-deficiency in populations of the mangrove Kandelia candel. Heredity 125: 47-52.

Clarke, P.J. \& P.J. Myerscough (1991). Floral biology and reproductive phenology of Avicennia marina in south-eastern Australia. Australian Journal of Botany 39: 283-293.

Clarke, P.J., R.A. Kerrigan \& C.J. Westphal (2001). Dispersal potential and early grow th in 14 tropical mangroves: do early life history traits correlate with patterns of adult distribution? Journal of Ecology 89: 648-659.

Cruden, R.W., S.M. Hermann \& S. Peterson (1983). Patterns of nectar production and plant-pollinator coevolution, pp. 80-125. In: Bentley, B. and T. Elias (ed.), The Biology of Nectaries, Columbia University Press, New York.

Cruden, R.W. (1977). Pollen-ovule Ratios: A conservative indicator of breeding systems in flowering plants. Evolution 31: 32-46.

Dafni, A., P.G. Kevan \& B.C. Husband (2005). Practical Pollination Biology. Enviroquest Ltd., Canada, 590pp.

Dahdouh-Guebas, F., M. Verneirt, J.F. Tack, D. Van Speybroeck \& N. Koedam (1998). Propagule predators in Kenyan mangroves and their possible effect on germination. Manual of Freshwater Research 49: 345-350.

Dress, W.J., S.J. Newell, A.J. Nastase \& J.C. Ford (1997). Analysis of amino acids in nectar from pitchers of Sarracenia purpurea (Sarraceniaceae). American Journal of Botany 84: 1701-1706.

Duke, N.C., M.C. Ball \& J.C. Ellison (1998). Factors influencing biodiversity and distributional gradients in mangroves. Global Ecology and Biogeography Letters 7: 27-47.

Faegri, K. \& van der Pijl (1979). The Principles of Pollination Ecology. Pergamon Press, New York, 243pp.

Farnsworth, E.J. \& J.M. Farrant (1998). Reductions in abscisic acid are linked with viviparous reproduction in mangroves. American Journal of Botany 85: $760-769$.

Gardener, M.C. \& M.P. Gillman (2002). The taste of nectar - a neglected area of pollination ecology. Oikos 98: 552-557.

Ge, J., B. Cai \& P. Lin (2003). Mating system and outcrossing rates of four Bruguiera gymnorrhiza populations of mangrove in China. Nature and Science 1: $42-48$.

Goldrich, N.R. (1973). Behavioural responses of Pharmia regina (Meigen) to labellar stimulation with amino acids. Journal of General Physiology 61: 74-88.

Joshi, A.C. (1933). A suggested explanation of the prevalence of vivpary on the sea-shore. Journal of Ecology 21: 209-212.

Juncosa, A.M. \& P.B. Tomlinson (1987). Floral development in mangrove Rhizophoraceae. American Journal of Botany 74: 1263-1279.

Kairo, J.G., F. Dahdouh-Guebas, J. Bosire \& N. Koedam (2001). Restoration and management of mangrove systems - a lesson for and from the East African regions. South African Journal of Botany 67: 383-389.

Kathiresan, K. \& A.N. Subramanian (2003). IUCN Conservation Status of Species, pp.47-50. In: Kathiresan, K. \& A.N. Subramanian (eds.). Biodiversity in Mangrove Ecosystems: UNU-UNESCO International Training Course Manual. Annamalai University, Chidambaram.

Kondo, K., T. Nakamura \& T. Tsuruda (1987). Pollination in Bruguiera gymnorrhiza and Rhizophora mucronata in Ishigaki Island, the Ryuku Islands, Japan. Biotropica 19: 377-380.

Little, E.L. Jr. (1983). Common fuelwood crops: A Handbook for their identification. McClain Printing Co., Parsons, WV, 123pp.

MacNae, W. (1968). A general account of the floral and fauna of mangrove swamps and forests in the Indo-West pacific regions. Advances in Marine Biology 6: 73-270.

Mangrove Status Report. Ministry of Environment and Forests (1987). Govt. of India, New Delhi, 150pp.

McGuinness, K.A. (1997). Dispersal, establishment and survival of Ceriops tagal propagules in a north Australian mangrove forest. Oecologia 198: 8087.

Meeuse, B. \& S. Morris (1984). The Sex Life of Flowers. Facts on File, New York,152pp.
Naskar, K. \& R. Mandal (1999). Ecology and biodiversity of Indian Mangroves Part-I Global Status, Daya Publishing House, New Delhi, $361 \mathrm{pp}$

Opler, P.A. (1983). Nectar production in a tropical ecosystem, pp.30-79. In: Bentley, B. \& T. Elias (eds.). The Biology of Nectaries, Columbia University Press, New York

Pannier, F. \& R.F. Pannier (1975). Physiology of vivpary in Rhizophora mangle, pp.632-642. In: Walsh, G.W., S.C. Snedaker \& H.J. Teas (eds.). Proceedings of the International Symposium on the Biology and Management of Mangroves. University of Florida Press, Gainesville, FL.

Perry, L.M. (1980). Medicinal plants of east and Southeast Asia. MIT Press, Cambridge, 632pp.

Rabinowitz, D. (1978). Mortality and initial propagules size in mangrove seedlings in Panama. Journal of Ecology 66: 45-51

Raju, A.J.S. (1990). Observations on the floral biology of certain mangroves. Proceedings of Indian National Science Academy 56: 367-374

Raju, A.J.S. (1990). The explosive pollination mechanism and mating system of the weedy mint, Hyptis suaveolens (Lamiaceae). Plant Species Biology. 5: 235-241.

Raju, A.J.S., K.H. Jonathan \& A.V. Lakshmi (2006). Pollination biology of Ceriops decandra (Griff.) Ding Hou (Rhizophoraceae), an important true viviparous mangrove tree species. Current Science 91: 1235-1238.

Ramasubramanian, R., T. Ravishankar \& D. Sridhar (2003). Mangroves of Andhra Pradesh: Identification and Conservation Manual. M.S. Swaminathan Research Foundation, Chennai, 67pp.

Reddi, C.S., A.J.S. Raju \& S.N. Reddy (1995). Pollination ecology of Avicennia officinalis L. (Verbenaceae). Journal of Palynology 31: 253-260.

Roubik, D.W. (1995). Pollination of Cultivated Plants in the Tropics. FAO Agricultural Services Bulletin 118, 196pp.

Selvam, V. \& V.M. Karunagaran (2004). Coastal Wetlands: Mangrove Conservation and Management Orientation Guide 1. Ecology and Biology of Mangroves. M.S. Swaminathan Research Foundation, Chennai, 61pp.

Shiraishi, A. \& M. Kuwabara (1970). The effects of amino acids on the labellar hair chemosensory cells of the fly. Journal of General Physiology 56: 768782 .

Singh, V.P. \& K. Odaki (2004). Mangrove Ecosystem: Structure and Function. Scientific Publishers, Jodhpur, 297pp.

Slansky, F. \& P. Feeny (1977). Stabilization of the rate of nitrogen accumulation by larvae of the cabbage butterfly on wild and cultivated food plants. Ecological Monographs 47: 209-228.

Sun, M., K.C. Wong \& J.S.Y. Lee (1998). Reproductive biology and population genetic structure of Kandelia candel (Rhizophoraceae), a viviparous mangrove species. American Journal of Botany 85: 1631-1637.

Thawley, A.R. (1969). The components of honey and their effects on its properties: A review. Bee World 50: 51-60.

Tomlinson, P.B. (1986). The Botany of Mangroves. Cambridge University Cambridge, 413pp.

Tomlinson, P.B., R.B. Primack \& J.S. Bunt (1979). Preliminary observations of floral biology in mangrove Rhizophoraceae. Biotropica 11: 256-277.

Untawale, A.G. (1986). India, Country Report: Asia. pp.5 1-87. In: Mangroves of Asia and the Pacific: Status and Management Technical Report of the UNDP/UNESCO, Research and Training Pilot Programme on Mangrove ecosystems in Asia and the Pacific, Quezon City, Manila,.

Yao, Y., S. Bera, Y. Wand \& C.S. Li (2006). Nectar and pollen sources for honeybee (Apis cerana cerana Fabr.) in Qingian Mangrove Area, Hainan Island China. Journal of Integrative Plant Biology 48: 1266-1273

\section{Author Details:}

K. Henry Jonathan is working as Senior Research Fellow from 2005 in a MoEF Research Project on Mangroves. He has registered for Ph.D. on Mangroves under Dr. Raju. He has published several research papers and has contributed articles on Eastern Ghats.

Dr. A.J. Solomon Raju is currently working as Associate Professor in the Department of Environment. He is the recipient of several national and international awards. He has more than 250 research papers in international and national Journals. $\mathrm{He}$ is on the editorial board of several international journals. He is presently working on the reproductive biology of mangrove plants and endemic and endangered plant species in the Eastern Ghats forests with financial support from the Ministry of Environment and Forests, DST and CSIR. 